\author{
TOMASZ STRYJEK \\ https://orcid.org/0000-0002-9137-7537 \\ Instytut Studiów Politycznych PAN \\ Collegium Civitas
}

\title{
MIĘDZY AFIRMACJĄ A DYSKREDYTACJĄ. O RZECZOWY OBRAZ ZIEM WSCHODNICH II RP*
}

\begin{abstract}
Abstrakt: Praca Kresowy kalejdoskop Włodzimierza Mędrzeckiego dotyczy procesów społecznych i przemian narodowościowych na Ziemiach Wschodnich II RP oraz polityki państwa wobec nich. W ocenie tej polityki autor uniknął stronniczości narodowej oraz teleologii i prezentyzmu. Mędrzecki nie odniósł się do modelu kolonializmu w interpretacji rządów Polski na Kresach w okresie międzywojennym. Jednak jego książka dostarcza materiału do rozmyślań nad przystawalnością tego modelu do historii relacji Polski z jej wschodnimi sąsiadami.
\end{abstract}

Słowa kluczowe: Ziemie Wschodnie II RP, Kresy Wschodnie, historia społeczna, mniejszości narodowe, modernizacja, kolonializm, teoria postkolonialna.
Abstract: The book Kresowy kalejdoskop (Kaleidoscopic Borderlands) by Włodzimierz Mędrzecki deals with social processes, and national and ethnic changes in the eastern territories of the Second Polish Republic as well as the state policy towards them. In his assessment of this policy, the author managed to avoid national bias as well as teleology and presentism. Mędrzecki did not refer to the model of colonialism in the interpretation of Polish rule in the Eastern Borderlands throughout the interwar period. His book, however, offers material for reflection on the relevance of this model to the history of Poland's relations with its eastern neighbours.

Keywords: Eastern Territories of the Second Polish Republic, Eastern Borderlands, social history, national minorities, modernization, colonialism, post-colonial theory.

* Uwagi o książce Włodzimierza Mędrzeckiego, Kresowy kalejdoskop. Wędrówki przez Ziemie Wschodnie Drugiej Rzeczypospolitej 1918-1939, Wydawnictwo Literackie, Kraków 2018, s. 419. 
Książka Kresowy kalejdoskop Włodzimierza Mędrzeckiego na tle całego jego dorobku z dwu powodów jawi się jako pozycja wyjątkowa. Po pierwsze, ze względu na szeroki zakres tematu i sposób jego potraktowania. Nie jest to ani monografia, ani synteza, lecz swego rodzaju panorama historii Ziem Wschodnich II Rzeczypospolitej z naciskiem na problemy cywilizacyjne, społeczne i ekonomiczne, podsumowująca prawie czterdziestoletnie badania Autora. Ważne miejsce znajdują w niej geografia ludności i demografia jako dyscypliny zajmujące się zjawiskami wpływającymi na życie społeczne w nie mniejszym stopniu niż rozwiązania polityczne czy różnice kulturowe. Po drugie, z uwagi na charakter popularnonaukowy. Reprezentuje typ pisarstwa jednocześnie adresowanego do wszystkich i spełniającego kryteria akademickie. Oprócz właściwego wykładu przynosi wiele informacji zawartych w podpisach ilustracji oraz biogramach. Pozycje tego typu okazują się być bardzo potrzebne wobec zalewu rynku opracowaniami popularnymi pisanymi przez ludzi, którzy wprost (często z motywacji merkantylnych) mitologizują poszczególne zjawiska i wydarzenia. Wskutek z jednej strony powściągliwości i rozwagi Autora w ocenach, z drugiej - nieprzeciążenia narracji szczegółami, książkę tę z satysfakcją przeczytają nie tylko profesjonaliści, ale także „zwykli” miłośnicy historii. Problem z nią będą mieli jedynie ci, którzy poszukują nie kompetentnej wiedzy, lecz potwierdzenia swych wyobrażeń czy uprzedzeń.

We „Wstępie” Autor zaprzecza, jakoby dążył do „odbrązowienia” legendy Kresów Wschodnich. Sądzę, iż jest to po trosze konsekwencja jego przekonania, że akademickiemu historykowi nie przystoi „schodzić" na poziom wspomnianych popularyzatorów, którzy wraz z dziennikarzami są obecnie najbardziej wpływowym aktorem kształtującym wyobrażenia Polaków o przeszłości. Prawdopodobnie uważa on też, że „odbrązawianie” może mieć taki sam związek z prawdą historyczną jak mitologizowanie. Jednak w istocie książka, przynosząc rzeczowy obraz Ziem Wschodnich, jest wielką polemiką ze współczesnymi obrazami popularnymi. Obraz stworzony przez Mędrzeckiego stanowi całościową alternatywę dla narracji opiewających sukces polskiej misji cywilizacyjnej oraz pokazujących polskie rządy na Wschodzie jako stan harmonijnego współżycia wielu narodowości i wyznań. Jego obiektywizm wyraża się w tym, że nie przyjmuje perspektywy żadnego z narodów, które zamieszkiwały wówczas Ziemie Wschodnie, nie czyni też kwestii narodowościowej głównym obiektem zainteresowania. Perspektywa Mędrzeckiego jest, podobnie jak $\mathrm{w}$ jego poprzednich pracach ${ }^{1}$, określona przede wszyst-

${ }^{1}$ Zob. W. Mędrzecki, Województwo wołyńskie 1921-1939. Elementy przemian cywilizacyjnych, społecznych i politycznych, Wrocław 1988; idem, Inteligencja polska na Wołyniu w okresie międzywojennym, Warszawa 2005. 
kim przez politykę państwa, działania elit inteligenckich oraz projekty modernizacji. Ziemie Wschodnie w okresie 1918-1939 interesują Autora jako obszar występowania problemów gospodarczych i konfliktów społecznych, w tym narodowościowych, które II RP usiłowała rozwiązać po to, aby zintegrować je z resztą państwa. Nie interesują go natomiast jako obszar czy to z jednej strony wielowiekowej dominacji kultury polskiej, czy to z drugiej - odwiecznej obrony Ukraińców, Białorusinów i Litwinów przed polonizacją.

Autor rozpoczyna swą opowieść rozdziałem przypominającym historię Kresów I Rzeczypospolitej do 1918 r. Nie przyjmuje paradygmatu narodowego, ale też nie występuje z perspektywy postkolonialnej. Zgodnie z tą ostatnią polskie elity od XIV do XVIII w. przewodziły ekspansji osadniczej na ziemiach na wschód od Przemyśla, Chełma i Białegostoku. Obróciły kraje obce im kulturowo i wyznaniowo w źródło swej potęgi majątkowej i politycznej w Rzeczypospolitej oraz surowcowe zaplecze Europy Zachodniej. W XVII-XVIII w. przekształciły własne państwo w atrapę i spowodowały jego upadek, uniemożliwiając nie tylko emancypację „własnego" ludu, ale także trzech innych narodów. Z kolei w okresie rozbiorowym nie były reprezentantem odrębnych tradycji politycznych, lecz lojalnym narzędziem panowania Rosji i Austrii. Zatarły przed polską opinią publiczną (także w następnych pokoleniach) to, że kierowały się przede wszystkim swoim interesem klasowym ${ }^{2}$. W końcu w II RP, konserwując pofeudalne stosunki na Ziemiach Wschodnich (jak nazywano województwa wschodnie w tym okresie), zdołały zachować dominację i obrócić w pustą formę zasadę równości obywatelskiej zawartą w konstytucji marcowej. W perspektywie kolonializmu Polakami na Kresach byli niemal bez wyjątku ziemianie oraz aparat urzędniczy trzymający w ryzach chłopów ukraińskich, białoruskich i litewskich.

W przypadku historii Kresów I Rzeczypospolitej, a następnie Ziem Wschodnich, za „parawanem” takiego podejścia łatwo można „ukryćc interpretacje dziejów, które jedynie „autochtonom” przyznają prawo do życia na nich. Niedaleko od takiego ujęcia historii Ukrainy, Białorusi i Litwy byli historycy radzieccy. Z kolei po 1991 r. silną pozycję w historiografii tych trzech państw zajęli narodowi esencjonaliści, którzy, wprawdzie gromko ogłosili zmianę paradygmatu, jednak w rzeczywistości zmienili dotychczasową interpretację o tyle, że w miejsce klas uciśnionych wstawili własną etniczną wspólnotę „autochtonów”. Autor

${ }^{2}$ J. Sowa, Fantomowe ciało króla. Peryferyjne zmagania z nowoczesna forma, Kraków 2011.

3 Zob. nр. В. Смолій, В. Степанков, Українська нац̧іональна революиія XVII cm. (1648-1676 pр.), Київ 1999. 
dostrzega w historiografiach naszych wschodnich sąsiadów badaczy bliższych własnemu podejściu, składając im podziękowania. Niemniej liczba ich prac w bibliografii książki ogranicza się do kilku. Badanie historii Ukrainy Zachodniej, Białorusi Zachodniej oraz Litwy Wschodniej w okresie międzywojennym w oparciu o źródła wytworzone przez państwo polskie i Polaków, a także badanie jej w perspektywie historii społecznej, wykraczającej poza paradygmat narodowy, nadal nie cieszy się w tych krajach powodzeniem.

Skądinąd trzeba zauważyć, że stosunki na tych ziemiach nie tylko do rozbiorów Rzeczypospolitej, ale także do rewolucji 1917-1921 (np. hierarchia kultur, ograniczenia możliwości awansu społecznego dla ludności innej niż Polacy, Rosjanie i Austriacy) spełniały niektóre kryteria kolonializmu4. W okresie międzywojennym ich konserwacji chciała większość ziemiaństwa, po 1926 r. sympatyzującego przeważnie z sanacją. Także zwolennicy obozu narodowego argumentowali za ich utrzymaniem jako środkiem gwarantującym dominację polskości oraz sprzyjającym asymilacji Ukraińców i Białorusinów. O podejściu władz zgodnym z modelem „wewnętrznego kolonializmu” może świadczyć to, że w ustawie o reformie rolnej wielkość majątków jej podlegających na Ziemiach Wschodnich podniesiono w stosunku do reszty terytorium Polski ze 180 do 300 ha, a także to, że, realizując ją, nie naciskano na ziemian, aby sprzedawali ziemię. Jednak jednocześnie - co pokazuje Mędrzecki - Polacy i państwo polskie byli na Ziemiach Wschodnich nie tylko ziemianami oraz przysłanymi z centrum osadnikami, urzędnikami i wojskowymi. Traktując je jako swoją ojczyznę, współtworzyli ich rozwój. Przy tym Autor w rozdziale pierwszym ukazuje nie tylko ich, ale także charakteryzuje pozycję społeczną Żydów, Ukraińców i Litwinów oraz przedstawia początki ich ruchów narodowych. Jako zbyt ogólnikowa w porównaniu z pozostałymi jawi się tu prezentacja ruchu białoruskiego, nawet biorąc pod uwagę to, że był on od nich znacznie słabszy.

W rozdziale drugim, poświęconym wojnom z Zachodnioukraińską Republiką Ludową i bolszewikami oraz konfliktowi z Litwą z lat 19181921, Autor zajmuje się koncepcją Józefa Piłsudskiego federalizacji z Polską ziem byłego Wielkiego Księstwa Litewskiego. Stwierdza, iż z jednej strony była ona wynikiem naiwności politycznej i słabego rozeznania politycznego Naczelnika w środowiskach litewskich i białoruskich,

${ }^{4}$ Odnośnie do okresu przedrozbiorowego zob. krytyki modelu kolonialnego, jednak zbyt uproszczone - J. Kieniewicz, O perspektywę dla Polski, w: Perspektywy postkolonializmu w Polsce, Polska w perspektywie postkolonialnej, red. idem, Warszawa 2016 (Debaty Artes Liberales, t. 10), s. 69-86; H. Grala, Rzeczpospolita szlachecka - twór kolonialny?, ibidem, s. 275-299. 
jednak z drugiej - wyrazem jego wiary w możliwość porozumienia się wielu narodowości jako alternatywy dla wybuchu konfliktu i nienawiści. Z kolei wojnę o Galicję Wschodnią przedstawia jako konflikt, do którego Polacy przystąpili z motywacją włączenia do państwa ważnego centrum życia narodowego. Jednocześnie konsekwencje zakończenia jej nie dyplomatycznym kompromisem, lecz zwycięstwem militarnym ocenia negatywnie. Zauważa, iż w II RP Lwów z „kosmopolitycznej, wielonarodowej i wielokulturowej stolicy habsburskiego kraju koronnego" przekształcił się w „polski bastion kresowy” (s. 70). Naświetla położenie Żydów, którzy po wkroczeniu w latach 1918-1919 wojsk polskich do miast na Ziemiach Wschodnich padli ofiarą pogromów, przede wszystkim we Lwowie i Wilnie. W konsekwencji nie stali się rzecznikami porozumienia z Polską na gruncie wspomnianej propozycji Piłsudskiego. Pokazuje źródła fiaska sojuszu Piłsudskiego z Symonem Petlurą i wspólnej wyprawy na Kijów z 1920 r.: z jednej strony sprzeciw ukraińskich chłopów wobec powrotu do majątków polskich ziemian, z drugiej - słabość oparcia dla idei niepodległości w społeczeństwie ukraińskim. Realistyczne podejście Mędrzeckiego jako badacza procesów społecznych skłania go do wnioskowania, że ziemianie (głównie Polacy) i wykształceni mieszkańcy miast (głównie Polacy i Żydzi) pozostali po wydarzeniach okresu 1917-1921 na Ziemiach Wschodnich głównymi siłami mogącymi zapewnić stabilizację władzy państwowej. Alternatywą dla nich byli bolszewicy, którzy w ZSRR wciągnęli do aparatu państwowego przedstawicieli dawnych elit Imperium Rosyjskiego.

Rozdziały trzeci, czwarty i piąty służą Autorowi do opisu różnych stron życia w międzywojennym Lwowie. W tej części książki najmocniej dochodzi do głosu konfrontacja współczesnej polskiej mitologii kresowej z rzeczywistością. W rozdziale trzecim Mędrzecki pokazuje, jak wyglądał Lwów w pamiętnikach przedstawicieli dobrze sytuowanych rodzin polskich i żydowskich, którzy w okresie międzywojennym przeżyli w nim dzieciństwo i młodość. Historyk uznaje pochodzący od nich sielankowy obraz życia w mieście za prawdziwy, ale wycinkowy. Jego zdaniem dziś problemem jest nie jego fałszywość, tylko jednostronność. Jest on w Polsce reprodukowany jako wyczerpujący lub przynajmniej jako jedyny zasługujący na uwagę, podczas gdy jego autorzy mieli ograniczoną percepcję świata społecznego z powodu zajmowania w nim wysokiej pozycji ${ }^{5}$.

${ }^{5}$ W inny sposób, konfrontując ze sobą źródła pochodzące od inteligencji ukraińskiej, polskiej, zasymilowanych Żydów, jednostronność tego obrazu Lwowa pokazała niedawno Ola Hnatiuk, zob. Odwaga i strach, Wrocław-Wojnowice 2015. 
Przeprowadzona przez Autora w rozdziale czwartym konfrontacja wizji pamiętnikarzy z rzeczywistością relacji polsko-ukraińskich i polsko-żydowskich usuwa w cień idylliczne rysy międzywojennego Lwowa. $\mathrm{Z}$ jednej strony przedstawia on środowiska wolnych zawodów (prawnicy, lekarze), które w Galicji były bardziej odporne na wpływ agitacji obozu narodowego niż w innych częściach ówczesnej Polski, bowiem wzory współżycia Polaków i Żydów czerpały z czasów habsburskich. Jednak z drugiej - pokazuje rosnące napięcie w pokoleniu dwudziesto-, trzydziestolatków wciągniętych już w ruchy nacjonalistyczne. Buta okazywana mniejszościom narodowym poprzez zapełnianie przestrzeni symbolicznej miasta przez Polaków (głównie w związku z budową Cmentarza Obrońców Lwowa na Łyczakowie), zamachy bojowców Ukraińskiej Organizacji Wojskowej i Organizacji Ukraińskich Nacjonalistów (OUN) na funkcjonariuszy państwa i osoby obciążone winą za „zdradę” narodu ukraińskiego, upokarzająca Ukraińców (choć w wymiarze policyjnym skuteczna) pacyfikacja wsi w Galicji Wschodniej przez wojsko na jesieni 1930 r., w końcu polskie praktyki dyskryminacyjne wobec Żydów (numerus clausus na uczelniach, napaści fizyczne i burdy studenckie na ulicach miasta), dobitnie obrazują „cienie” procesu kształtowania się nowoczesnego społeczeństwa w II RP jako polskim państwie narodowym. Z kolei w rozdziale piątym Mędrzecki „nakłada” strukturę narodowościową miasta na strukturę społeczną. Przedstawia dużą skalę bezrobocia i bezdomności, niewydolność państwa w zmaganiu się ze skutkami kryzysu gospodarczego lat trzydziestych, histerię antykomunistyczną służb państwowych, które nie potrafiły zapanować nad nastrojami społecznymi i dopuściły do wybuchu fali manifestacji i walk ulicznych w kwietniu 1936 r. Autor rysuje też proces prowincjonalizacji Lwowa przez administrację centralną z Warszawy, co było dotkliwym doświadczeniem jego mieszkańców po okresie galicyjskiej stołeczności do 1918 r. Przekonująco podsumowuje bilans dwudziestolecia w mieście słowami, które oddawały przekonania starszych mieszkańców: „lepiej już było”.

Rozdział szósty książki zawiera charakterystykę wschodniogalicyjskiej prowincji. Tu na pierwszym planie Autor przedstawia proporcje liczebne narodowości i stosunki między nimi. Wydobywa przejawy postaw obronnych społeczności wiejskich wobec nacisku państwa na zadeklarowanie jednoznacznej identyfikacji narodowej. Przedstawia zawodność metodologii wnioskowania o przynależności narodowej ludności do Polaków, Żydów i Ukraińców/Rusinów na podstawie jedynie danych spisowych dotyczących wyznania i języka. Wskazuje „plebiscyty” językowe w szkołach, przymusowe uczestnictwo w świętach państwowych, inwigilację przez policję (m.in. raporty konfidentów informujących władze 
o nastrojach społecznych), jako pola konfrontacji mieszkańców z naciskiem państwa ${ }^{6}$. Przytacza przykłady sytuacji, w których podejmowanie przez jednostki odmiennych wyborów identyfikacyjnych prowadziło do rozrywania lokalnych więzi społecznych.

Z innymi wyzwaniami - przekonuje Mędrzecki - spotkało się państwo polskie w województwie wołyńskim (rozdział siódmy). Podsumowując swoje wieloletnie badania tego regionu, Autor wystawia polityce władz w sumie lepszą ocenę niż w Galicji Wschodniej. Inaczej niż w dawnym zaborze austriackim, na Wołyniu narodowa działalność ukraińska była znacznie słabsza, ale rząd - zwłaszcza po przewrocie majowym stał tu wobec opozycji także dwu innych sił. Byli to z jednej strony polscy ziemianie, którzy sprzeciwiali się projektom modernizacji wsi w obawie przed demokratyzacją stosunków społecznych, z drugiej - znajdujący oparcie głównie w Ukraińcach ruch komunistyczny i radianofilski.

Mędrzecki wysoko ocenia efekty pracy polskiej inteligencji na Wołyniu, która w ciągu dwudziestolecia zbudowała niemal od zera administrację i szkolnictwo oraz rozwinęła życie kulturalne. Założenia i cele „eksperymentu wołyńskiego" Henryka Józewskiego (1930-1938), powiązane z polityką prometejską państwa wobec Europy Wschodniej, uznaje za efekt trzeźwej analizy sytuacji. Zaznacza, iż w stosunku do swych wcześniejszych prac na temat Wołynia odszedł od krytyki koncepcji ugody polsko-ukraińskiej wojewody jako pomysłu narzucającego „sztuczne” rozwiązanie i skłonił się ku uznaniu jej za najbardziej „rozsądną polską strategię działania" w ówczesnych realiach międzynarodowych. Być może tym właśnie można wyjaśnić to, że Autor łagodnie ocenia „rewers” polityki Józewskiego na Wołyniu: bezwzględne zwalczanie konkurentów dla lojalistów wśród Ukraińców metodami policyjnymi. Już sama liczba 4455 aresztowanych w okresie jego rządów pod zarzutem przynależności do Komunistycznej Partii Zachodniej Ukrainy jawi się jako wysoka. Wątpliwości budzi to, czy skuteczny mógł być program, w ramach którego zniszczono wszystkie niezależne instytucje ukraińskie, aby zastąpić je instytucjami dwunarodowymi. Ostatecznie Autor ocenia, iż o niepowodzeniu programu zadecydowały czynniki od wojewody niezależne: kryzys gospodarczy lat trzydziestych oraz jego przeciwnicy w Warszawie, którzy doprowadzili do odsunięcia go, argumentując, iż zagrożenie Polski ze strony III Rzeszy i ZSRR zmusza państwo do wspierania wyłącznie polskości.

W rozdziale ósmym pokazuje Mędrzecki rządy II RP w Wilnie w latach 1922-1939 jako okres większego niż we Lwowie postępu moderniza-

${ }^{6}$ Zob. O. Linkiewicz, Lokalność i nacjonalizm. Społeczności wiejskie w Galicji Wschodniej $w$ dwudziestoleciu międzywojennym, Kraków 2018. 
cyjnego (jednak poziom „startowy” był tu niższy), ale także nieodpowiadającego nadziejom, jakie mieszkańcy wiązali z powstaniem tego państwa. Również w tym przypadku przedstawia „blaski” (głównie rozwój polskiego życia artystycznego i naukowego) i „cienie” (m.in. wystąpienia antyżydowskie) historii społecznej miasta. Inaczej niż ruch ukraiński we Lwowie, litewski ruch narodowy w Wilnie był zbyt słaby, aby rzucić wyzwanie dominacji Polaków.

Rozdział dziewiąty zamyka panoramę Ziem Wschodnich w książce charakterystyką województw wileńskiego i nowogródzkiego. Autor rysuje w nim słabość ośrodków miejskich poza Wilnem i konieczność budowy przez państwo struktur administracyjnych niemal całkiem od podstaw. Przedstawia spadek w okresie międzywojennym dochodów wielkiej własności ziemskiej oraz brak poprawy położenia biednego chłopstwa. Tendencje te zostały jeszcze pogłębione przez światowy kryzys gospodarczy lat trzydziestych oraz klęski powodzi i suszy w latach 1928, 1933 i 1937.

Podobnie jak w rozdziale pierwszym ludność białoruska oraz polityka państwa wobec niej w charakterystyce ziem północno-wschodnich w ostatnich dwu rozdziałach pracy zajmuje niewiele miejsca. W rozdziale dziewiątym Autor ograniczył się do informacji o represyjnych wobec organizacji białoruskich i jednoznacznie asymilacyjnych wobec Białorusinów działaniach wojewody wileńskiego Ludwika Bociańskiego w latach 1936-1939. W rozdziale dziesiątym napisał zwięźle o zjawisku „tutejszości” jako wyrazie odrzucenia nowoczesnych tożsamości narodowych oraz o Białoruskiej Włościańskiej Hromadzie jako ruchu społecznym bardziej o charakterze chłopskim niż narodowym. W warstwie faktograficznej jest to wystarczające. Jednak szkoda, że nie poświęcił temu zagadnieniu w książce więcej miejsca. W województwach poleskim, nowogródzkim, wileńskim i białostockim żyło łącznie nie mniej niż milion ludzi nieuznających się za Polaków, Żydów, Litwinów czy Ukraińców. Nie byli przedmiotem takiej agitacji narodowej, jak ludność Wołynia ze strony ukraińskich organizacji z Galicji, natomiast, podobnie jak ona, byli poddani wpływowi polityki ZSRR i BSRR wobec II RP. Byłoby bardzo interesujące przeczytać, jak znawca „eksperymentu wołyńskiego” porównawczo ocenia perspektywy poprowadzenia przez państwo analogicznego programu wobec słabiej ożywionej politycznie niż Ukraińcy wołyńscy, ale też mającej poczucie odrębności, białoruskiej ludności ziem północno-wschodnich.

Przedmiotem oceny w „Podsumowaniu” są wyniki pracy państwa polskiego nad rozwojem i integracją Ziem Wschodnich. Przeważają rysy negatywne. Mędrzecki stwierdza, iż podjęto duży wysiłek - w tej części Polski państwo więcej wydawało niż zbierało z podatków - ale efekty 
były mizerne. Nie rozwiązano żadnego wielkiego problemu: analfabetyzmu, archaicznych metod uprawy roli, braku przemysłu i infrastruktury, przeludnienia i bezrobocia. Autor wskazuje działania państwa, które spełniają kryteria modelu kolonialnego, choć ich tak nie nazywa. Po pierwsze, polskie elity przyznawały wyraźną preferencję rozwiązywaniu problemów społecznych ziem centralnych. Po drugie, aparat państwa na Ziemiach Wschodnich pod względem narodowościowym był czysto polski. Strategię polegającą na wykluczeniu nie-Polaków i nie-rzymskich katolików oraz zepchnięciu ich na pozycję potencjalnych przeciwników II RP nazywa Mędrzecki „samobójczą”. Po trzecie, pomimo deklaracji składanych przez sanację na rzecz polityki asymilacji państwowej, w ocenie Autora po 1926 r. polityka asymilacji narodowej była nadal prowadzona. Co więcej, od 1935 r. państwo wzmogło akcję polonizacyjną, a niektórzy decydenci w instytucjach centralnych zaczęli jawnie głosić asymilację narodową.

Ostatecznie formuła II RP jako polskiego państwa narodowego jawi się Mędrzeckiemu jako poważny błąd. Wprawdzie - zaznacza on - prowadząc alternatywną politykę wobec mniejszości, państwo nie mogło ani zapobiec deportacji przez ZSRR elit społecznych w latach 1940-1941, ani odciągnąć ukraińskiego ruchu niepodległościowego od orientacji na Niemcy i powstrzymać rozprawy OUN-UPA (Ukraińska Powstańcza Armia) z Polakami w latach 1943-19447, jednak mogło mieć bardziej nowoczesną wizję rozwoju Ziem Wschodnich. Jego polityka w latach 1918-1939 polegała głównie na „gaszeniu pożarów”, a nie usuwaniu ich źródeł.

Zgadzam się z Autorem zarówno co do oceny polityki II RP wobec nie-Polaków, jak co do błędności wyjaśnienia, iż, dyskryminując i upokarzając ich, prostą drogą prowadziła ona do zbrodni radzieckich i ukraińskich na Polakach na Ziemiach Wschodnich w latach 1939-1944. W historiografii w Polsce i na Ukrainie pojawiły się w ostatnich latach pozycje, których autorzy charakteryzują rządy I i II Rzeczypospolitej na tym obszarze właśnie jako jedno pasmo działań prowadzących do krwawego finału w postaci antypolskiej akcji OUN-UPA na Wołyniu i w Galicji Wschodniej w latach 1943-1944. Ich autorzy powołują się na prace Daniela Beauvois, którego opis panowania polskiej szlachty nad ukraińskimi chłopami w południowo-zachodnich guberniach Imperium Rosyjskiego w XIX w. odpowiada modelowi kolonialnemu ${ }^{8}$.

7 Zob. też W. Mędrzecki, Inteligencja polska, s. 270-271.

${ }^{8}$ D. Beauvois, Trójkąt ukraiński. Szlachta, carat i lud na Wołyniu, Podolu i Kijowszczyźnie 1793-1914, Lublin 2005. Zob. też B. Bakuła, Kolonialne i postkolonialne aspekty polskiego dyskursu kresoznawczego (zarys problematyki), „Teksty Drugie” 2006, 6, s. 11-33; D. Beauvois, Autobiografia i teksty wybrane, Warszawa 2017. 
Wspominając o pozycjach z ostatnich lat, w mniejszym stopniu mam na myśli przywołaną już pracę Jana Sowy. Wprawdzie jego postkolonialne podejście do I Rzeczypospolitej i okresu rozbiorowego zaowocowało powstaniem jednostronnej interpretacji źródeł polsko-ukraińskiego węzła historycznego, jednak jeśli ktoś chce wyprowadzać z jego pracy wyjaśnienie zbrodni z lat czterdziestych XX w. obciążające wyłącznie Rzeczpospolitą, powinien czynić to na własną odpowiedzialność 9 . Niemal wprost wyraża je natomiast kolejny zwolennik interpretacji Beauvois, ukraiński historyk Bohdan Hud. Przekonuje, że „wydarzenia na Wołyniu i w Galicji Wschodniej w latach 1942-1946 miały cechy wojny domowej, chłopskiej i religijnej jednocześnie", polemizuje z tezą o głównej odpowiedzialności OUN i UPA za ówczesne zbrodnie na Polakach i sugeruje, iż ich źródłem były przede wszystkim wielowiekowe, brutalne rządy obcych elit na Ukrainie. Właśnie ten autor cytuje Mędrzeckiego jako polskiego badacza rzetelnie opisującego niesprawiedliwości zadane Ukraińcom w II RP i w związku z tym zbieżnego ze sobą w interpretacji źródeł tamtejszych konfliktów ${ }^{10}$. Mędrzecki w 2002 r. faktycznie napisał, iż jednym ze źródeł antypolskiej akcji OUN-UPA były dążenie do „zapłaty” za „pańskie/polskie” rządy oraz podkreślił chłopski charakter konfliktu na Wołyniu w latach 1943-1944 ${ }^{11}$. Jednak z jego tekstów nie da się wyprowadzić wniosku, iż te okoliczności w istotny sposób pomniejszają odpowiedzialność za zbrodnie kierownictwa ukraińskiego podziemia.

Autor Kresowego kalejdoskopu cieszy się zasłużoną renomą badacza obiektywnego, niewahającego się wyrażać krytyczne oceny polityki Polski w przeszłości. Jednak jego prac o Kresach/Ziemiach Wschodnich nie da się wpisać ani w teorię postkolonialną, ani w koło wzajemnych oskarżeń o to, która strona - Polacy i Ukraińcy - ponosiła główną czy wręcz wyłączną odpowiedzialność za wydarzenia z lat czterdziestych kończące okres polsko-ukraińskiego współżycia na Ziemiach Południowo-Wschodnich/Ukrainie Zachodniej.

9 J. Sowa, op. cit.

${ }^{10}$ B. Hud, Ukraińcy i Polacy na Naddnieprzu, Wołyniu i w Galicji Wschodniej w XIX i pierwszej połowie XX wieku, Warszawa 2018, s. 285, 326, 349. W sposób radykalnie symplicystyczny podejście postkolonialne do całej historii stosunków polsko-ukraińskich, w tym zbrodni w konflikcie z lat 1939-1947, zastosował natomiast historyk i publicysta „Naszego Słowa” w Warszawie Bogdan Huk, zob. Ukraina. Polskie jądro ciemności, Przemyśl 2013.

11 Zob. W. Mędrzecki, Polityka narodowościowa II Rzeczypospolitej a antypolska akcja UPA w latach 1943-1944, w: Antypolska akcja OUN-UP 1943-1944. Fakty i interpretacje, red. G. Motyka, D. Libionka, Warszawa 2002, s. 19-32. 
Po lekturze jego pracy nabrałem przekonania, iż bardzo przydatne byłoby, gdyby historycy pokazali, które elementy modelu kolonialnego pasują, które zaś nie pasują do rządów Rzeczypospolitej oraz polskich elit na obszarze Ukrainy, Białorusi i Litwy w poszczególnych epokach. Zrobienie tego przez takich znawców tej problematyki, jak Włodzimierz Mędrzecki, wpłynęłoby na dyskusję z jednej strony o odpowiedzialności za konflikty polsko-ukraińskie, z drugiej zaś - nad specyfiką całej historii Polski. Sowa, publikując wspomnianą pracę w 2011 r., przyczynił się jedynie do krótkotrwałej debaty nad drugą z tych kwestii. Myślę, że dziś warto zmierzyć się także z pierwszą. Poważnie traktując „wyzwanie kolonialne" we współczesnej humanistyce, polscy badacze mogą przyczynić się do rozwoju historiografii tak we własnym kraju, jak i u naszych wschodnich sąsiadów.

\section{Streszczenie}

Książka Włodzimierza Mędrzeckiego Kresowy kalejdoskop. Wędrówki przez Ziemie Wschodnie Drugiej Rzeczypospolitej 1918-1939 (Kraków 2018) jest przede wszystkim próbą spojrzenia na politykę II RP wobec jej Ziem Wschodnich przez pryzmat zachodzących tam procesów społecznych i przemian narodowościowych. Dokonując przeglądu sytuacji we wszystkich siedmiu województwach „kresowych”, autor pokazał, iż w wyniku wieloletnich badań stał się znawcą nie tylko problematyki ukraińskiej okresu 1918-1939, ale także żydowskiej, białoruskiej i litewskiej. Jego ocena polityki II RP jest naznaczona silnym krytycyzmem. Władze Polski zrobiły za mało na rzecz przełamania prowincjonalności Ziem Wschodnich, a elity ludności nieidentyfikującej się z polskością, zamiast przyciągnąć do państwa, wręcz odepchnęły.

Autor książki uniknął zagrożenia „wpłynięcia na mieliznę” poznania historycznego, które odnośnie do Kresów Wschodnich czyha na przedstawicieli paradygmatu z jednej strony narodowego, z drugiej - postkolonialnego. Niemniej ci ostatni nadal nie powiedzieli ostatniego słowa w historiografii światowej. Co więcej, w ostatnich latach wydają się zyskiwać uznanie w historiografii ukraińskiej zajmującej się rządami I i II RP oraz polskich elit na Ukrainie. Historycy ukraińscy wykorzystują schemat ucisku klasowego i represyjnego państwa do 1939 r. do wyjaśnienia źródeł masowych zbrodni UPA na ludności polskiej Wołynia i Galicji Wschodniej w latach 1943-1944. W polskiej humanistyce na „wyzwanie kolonialne” w badaniach historii Kresów odpowiedzieli dotychczas głównie literaturoznawcy i kulturoznawcy, nie zaś historycy dziejów społecznych i politycznych. Wydaje się, że przed polskimi historykami stoi zadanie krytycznego przeglądu modelu panowania kolonialnego celem wskazania, które jego elementy pasowały, które zaś nie pasowały do rzeczywistości historycznej w poszczególnych epokach. 


\section{Between Affirmation and Discrediting. For An Image of Reality in the Eastern Lands of the Second Polish Republic}

Włodzimierz Mędrzecki’s Kresowy kalejdoskop. Wędrówki przez Ziemie Wschodnie Drugiej Rzeczypospolitej 1918-1939 (Kaleidoscopic Borderlands. Journeys through the Eastern Lands of the Second Polish Republic, 1918-1939, Kraków, 2018) is, first and foremost, an attempt to look at the policy of the Second Polish Republic towards its Eastern Territories through the prism of social processes and national changes taking place there. Reviewing the situation in all seven "borderland" voivodeships, the author demonstrated that, after many years of research, he is an expert not only in Ukrainian, but also in Jewish, Belarusian and Lithuanian issues in the period between 1918 and 1939. His opinion about the policy of the Second Polish Republic is highly critical. The Polish authorities did much too little to overcome the provinciality of the Eastern Territories, and at the same time, instead of attracting the elites of the non-Polish population to the state, pushed them away.

Mędrzecki skilfully avoided the cognitive traps of the Eastern Borderland's history laid for representatives of the paradigm, on the one hand - national, while on the other - post-colonial. Nevertheless, these latter have still not said the last word in world historiography. What is more, in recent years they seem to gain increased recognition in the Ukrainian historiography on the First and Second Polish Republic and Polish elites in Ukraine. Ukrainian historians use the scheme of class oppression and the repressive state before 1939 to explain the reasons for mass crimes of the UPA against the Polish population in Volhynia and Eastern Galicia in 1943-1944. In the Polish humanities, the "colonial challenge" in the historical studies of the Borderlands has been taken up mainly by literary and culture specialists, and not by scholars of social and political history. It seems that Polish historians are faced with the task of critically reviewing the model of colonial rule to indicate which of its elements fitted, and which did not match the historical reality in individual periods of time.

\section{Bibliografia}

Bakuła Bronisław, Kolonialne i postkolonialne aspekty polskiego dyskursu kresoznawczego (zarys problematyki), „Teksty Drugie” 2006, 6, s. 11-33.

Beauvois Daniel, Autobiografia i teksty wybrane, IHN PAN - ASPRA-JR, Warszawa 2017.

Beauvois Daniel, Trójkąt ukraiński. Szlachta, carat i lud na Wołyniu, Podolu i Kijowszczyźnie 1793-1914, UMCS, Lublin 2005.

Grala Hieronim, Rzeczpospolita szlachecka - twór kolonialny?, w: Perspektywy postkolonializmu $w$ Polsce, Polska $w$ perspektywie postkolonialnej, red. Jan Kieniewicz, Wydział „Artes Liberales”, UW, Warszawa 2016 (Debaty Artes Liberales, t. 10), s. 275-299.

Hnatiuk Ola, Odwaga i strach, KEW, Wrocław-Wojnowice 2015. 
Hud Bohdan, Ukraińcy i Polacy na Naddnieprzu, Wołyniu i w Galicji Wschodniej w XIX i pierwszej połowie XX wieku, Pracownia Wydawnicza, Warszawa 2018.

Huk Bogdan, Ukraina. Polskie jądro ciemności, Stowarzyszenie Ukraińskie Dziedzictwo, Przemyśl 2013.

Kieniewicz Jan, O perspektywe dla Polski, w: Perspektywy postkolonializmu w Polsce, Polska w perspektywie postkolonialnej, red. Jan Kieniewicz, Wydział „Artes Liberales”, UW, Warszawa 2016 (Debaty Artes Liberales, t. 10), s. 69-86.

Linkiewicz Olga, Lokalność i nacjonalizm. Społeczności wiejskie w Galicji Wschodniej w dwudziestoleciu międzywojennym, Universitas, Kraków 2018.

Mędrzecki Włodzimierz, Inteligencja polska na Wołyniu w okresie międzywojennym, Neriton - IH PAN, Warszawa 2005.

Mędrzecki Włodzimierz, Kresowy kalejdoskop. Wędrówki przez Ziemie Wschodnie Drugiej Rzeczypospolitej 1918-1939, Wydawnictwo Literackie, Kraków 2018.

Mędrzecki Włodzimierz, Polityka narodowościowa II Rzeczypospolitej a antypolska akcja UPA w latach 1943-1944, w: Antypolska akcja OUN-UP 1943-1944. Fakty i interpretacje, red. Grzegorz Motyka, Dariusz Libionka, IPN - KŚZpNP, Warszawa 2002, s. 19-32.

Mędrzecki Włodzimierz, Województwo wołyńskie 1921-1939. Elementy przemian cywilizacyjnych, społecznych i politycznych, Ossolineum, Wrocław 1988.

Sowa Jan, Fantomowe ciało króla. Peryferyjne zmagania z nowoczesna forma, Universitas, Kraków 2011.

Смолій Валерій, Степанков Валерій, Українська нацзіональна революизія XVII cm. (1648-1676 рр.), Видавництво „Альтернативи”, Київ 1999.

Biog ram: Tomasz Stryjek, dr hab., profesor nadzwyczajny Instytutu Studiów Politycznych PAN, wykładowca Collegium Civitas, historyk i politolog. Obszar zainteresowań naukowych: historiografia, ideologie narodowe, procesy narodotwórcze w XIX-XX w. oraz współczesna polityka pamięci w Europie Wschodniej i Południowo-Wschodniej; kontakt: tstryjek@wp.pl. 